\title{
Malting barley response to integrated organic and mineral nutrient sources in Nitisol
}

\author{
Kassu Tadesse ${ }^{1}$ (1) $\cdot$ Asrat Mekonnen $^{1} \cdot$ Almaz Admasu $^{1} \cdot$ Wubengda Admasu $^{1} \cdot$ Dawit Habte $^{1} \cdot$ Amare Tadesse $^{1}$. \\ Bahiru Tilahun ${ }^{1}$
}

Received: 2 August 2017 / Accepted: 23 January 2018 / Published online: 1 February 2018

(c) The Author(s) 2018. This article is an open access publication

\begin{abstract}
Purpose Depletion of soil fertility accounts for the low yield and quality of malting barley (Hordeum vulgare) in Ethiopia. Mineral fertilizers can counteract nutrient depletion but are unaffordable by low-input farmers. Organic amendments can contribute to correct soil degradation but are often unavailable in the required amounts. Therefore, this experiment was conducted to investigate the effects of combined use of organic and mineral amendments on the yield and quality of malting barley, and on selected soil chemical properties at Lemu-Bilbilo district in the southeastern highlands of Ethiopia.

Methods Eight treatments were arranged in randomized complete block design with three replications to compare sole and integrated applications of organic and mineral nutrient sources on crop performance attributes and selected soil characteristics. Results Application of $2.82 \mathrm{t} \mathrm{ha}^{-1}$ compost or $1.07 \mathrm{t} \mathrm{ha}^{-1}$ farmyard manure (FYM) along with $18-10 \mathrm{~kg} \mathrm{ha}^{-1} \mathrm{~N}-\mathrm{P}$ gave $4234-4443 \mathrm{~kg} \mathrm{ha}^{-1}$ grain yield with $15-17$ and 32-39\% increase over sole organic amendments and control, respectively, and $757 \%$ economic benefit. Combining organic and mineral fertilizers also gave $7-17$ and $1-6 \%$ increase in available soil $\mathrm{P}$ and total $\mathrm{N}$ content of the soil.

Conclusion Combined application of 50\% recommended compost (RC) or 50\% recommended FYM (RFYM) + 50\% recommended NP (RNP) or 33\% RC + 33\% RFYM + 33\% RNP enhanced yield, grain quality, soil attributes and economic benefits. Therefore, integration of organic and mineral amendments is recommended as best agronomic and economic optimum soil fertility management options for sustainable malting barley production in the southeastern highlands of Ethiopia.
\end{abstract}

Keywords Compost $\cdot$ Ethiopia $\cdot$ Farmyard manure $\cdot$ Hordeum vulgare $\cdot$ Mineral fertilizers

\section{Introduction}

Barley (Hordeum vulgare L.) ranks fifth next to teff (Eragrostis tef), maize (Zea mays), sorghum (Sorghun bicolor) and wheat (Triticum aestivum) in Ethiopia, and third after wheat and teff in the southeastern highlands of Ethiopia. It is grown annually on 1 million hectares of land in a wide range of environments in the country (CSA 2014). Malting barley is one of the most important crops for food, feed, malt and income generation for many smallholder farmers in the highlands of Ethiopia (FAO 2013; Mulatu and Lakew 2011).

Malting barley accounts for about $90 \%$ of the raw materials cost in beer production in Ethiopia (USDA GAIN 2014).

Kassu Tadesse

kasstad96@yahoo.com

1 Kulumsa Agricultural Research Center, Ethiopian Institute of Agricultural Research, P. O. Box 489, Kulumsa, Ethiopia
It has become a very important industrial crop in the country since the establishment of Saint George Brewery in 1974. The demand for malting has increased further since the establishment of Assela malt factory in 1984. The inauguration of Gonder malt factory in 2015 and the blooming of many more breweries created greater demands for malting barley (Berhane et al. 2016).

Ethiopia has favorable environment and considerable market opportunities for increased production of highquality malting barley; however, its production has not been expanded enough to benefit most barley growers, malt factories and breweries (Berhane et al. 2016). Regardless of the huge potential, domestic production could satisfy only $55 \%$ of the raw malt barley demand of the country; the remainder has been imported from different countries. The share of malting barley production is about $10-15 \%$ as compared to food barley (Berhane et al. 2016). 
Low soil fertility and poor agronomic practices are among the major constraints responsible for the low productivity of malting barley in Ethiopia (Gete et al. 2010). Low soil fertility in turn resulted from farming without replenishing nutrients over time, continuous cropping of cereals, removal of crop residues, nutrient leaching, low level of fertilizer usage and unbalanced application of nutrients. The problem of soil fertility degradation is most pronounced in the highlands of Ethiopia, where most of human and livestock population concentrated, and malting barley is produced (Getachew et al. 2014b). The average annual top soil loss from agricultural lands is estimated to be 137 tons $\mathrm{ha}^{-1}$ year $^{-1}$ for the Ethiopian highlands (Gete et al. 2010). Regardless of the sever soil degradation, the use of external inputs to maintain soil fertility for increasing malting barley production is still low. In 2014, for example, only 5973 ton of fertilizer was used to nourish barley sown on 91,617 hectare of land in the study area indicating the rate used $\left(65 \mathrm{~kg} \mathrm{ha}^{-1}\right)$ was lower than the existing recommendation, which was $100 \mathrm{~kg} \mathrm{ha}^{-1}$ diammonium phosphate (18-20 kg ha $\left.{ }^{-1} \mathrm{~N}-\mathrm{P}\right)$ (CSA 2014).

Proper fertilizer management is required to counteract soil fertility depletion, increase production at required quality and satisfy the increasing demand of malting barley. However, experiences showed that focusing on separate interventions will no longer work. There has been a fivefold increase in fertilizer application since the 1980s, but the increase in the national cereal yield was only $10 \%$ (Gete et al. 2010). Besides, continuous applications of inorganic fertilizers alone resulted in deterioration of soil health in terms of soil physical, chemical and biological properties (Getachew et al. 2014b). The results of previous studies indicated that application of inorganic or organic fertilizers alone did not bring a sustainable increase in yields (Getachew et al. 2014a).

While mineral fertilizers such as diammonium phosphate and urea are widely used for cereals production in Ethiopia, such amendments are no longer affordable for resource-poor farmers at recommended application rates. On the other hand, organic amendments are often not available on farm at the amounts required (Agegnehu and Amede 2017). The best alternative is integrating organic and mineral fertilizers for tackling soil fertility depletion and sustainably increasing crop yields (Agegnehu and Amede 2017; Getachew et al. 2014b; Gete et al. 2010).

However, information on the integrated uses of organic and mineral amendments and their effects on yield and grain quality of malting barley, and soil chemical properties in the southeastern highland of Ethiopia, where this study was conducted, is scarce. This field experiment was, therefore, conducted to contribute for the development of appropriate nutrient management strategies that can sustain malting barley production, improve the livelihood of farmers and satisfy the increasing demands from the brewing industry in Ethiopia. The specific objectives were to investigate the effects of combined uses of organic and mineral amendments on the yield and quality of malting barley and selected soil chemical properties. The specific objectives also included determination of the economically optimum application rates of integrated organic and inorganic fertilizers for improving the yield and attributes of malting barley.

\section{Materials and methods}

\section{Description of study sites}

A 2-year study was conducted on five farmers' fields at Lemu-Bilbilo district in the southeastern highlands of Ethiopia between 2013 and 2014. Lemu-Bilbilo district has a high potential for both food and malting barley production. Its climate is characterized as warm temperate sub-humid to humid (Atlas of Arsi Zone 2002). The dominant soil at the experimental sites is classified as Nitisol (IUSS Working Group 2014). The study sites were located between $7^{\circ} 10^{\prime} 14^{\prime \prime}$ to $7^{\circ} 40^{\prime} 20^{\prime \prime} \mathrm{N}$ latitude and $39^{\circ} 4^{\prime} 59^{\prime \prime}$ to $39^{\circ} 38^{\prime} 56^{\prime \prime} \mathrm{E}$ longitude at altitudes ranging from 2633 to $2755 \mathrm{~m}$ a.s.l. (Fig. 1).

The long-term mean annual rainfall was $1053 \mathrm{~mm}$. The rainy season starts in March and continues to October with the highest precipitation occurring in July and August (Fig. 2). The mean annual minimum and maximum temperatures of the study area are 7.07 and $19.42{ }^{\circ} \mathrm{C}$, respectively. November and March are the coldest and hottest months with temperatures of 6.09 and $21.34{ }^{\circ} \mathrm{C}$, respectively.

\section{Soil sampling procedures and chemical analysis}

A total of 21 composite soil samples, three for each location, were collected at a depth of $0-40 \mathrm{~cm}$ before planting for soil characterization. Composite soil samples were also collected immediately after harvesting from each site for investigating the changes in soil chemical properties due to treatments application. The soil samples were air dried, grounded to pass to $2 \mathrm{~mm}$ sieve, and analyzed for $\mathrm{pH}$ using 1:2.5 soil: water ratio (Mclean 1982); total nitrogen (N) using Kjeldahl digestion with sulfuric acid catalyzed by potassium sulfate (He et al. 1990) and available phosphorous (P) using Mehlich III extraction method (Mehlich 2008) at the soil and plant nutrition laboratory of Kulumsa Agricultural Research Center.

\section{Preparation of compost and farmyard manure (FYM)}

Compost was prepared by pit method from $40 \%$ maize and wheat crop residues, $25 \%$ animal manure, $20 \%$ green alfalfa leaves, $10 \%$ ash and $5 \%$ forest soil. FYM was made of fresh cow dung, urine and organic bedding materials for dairy 


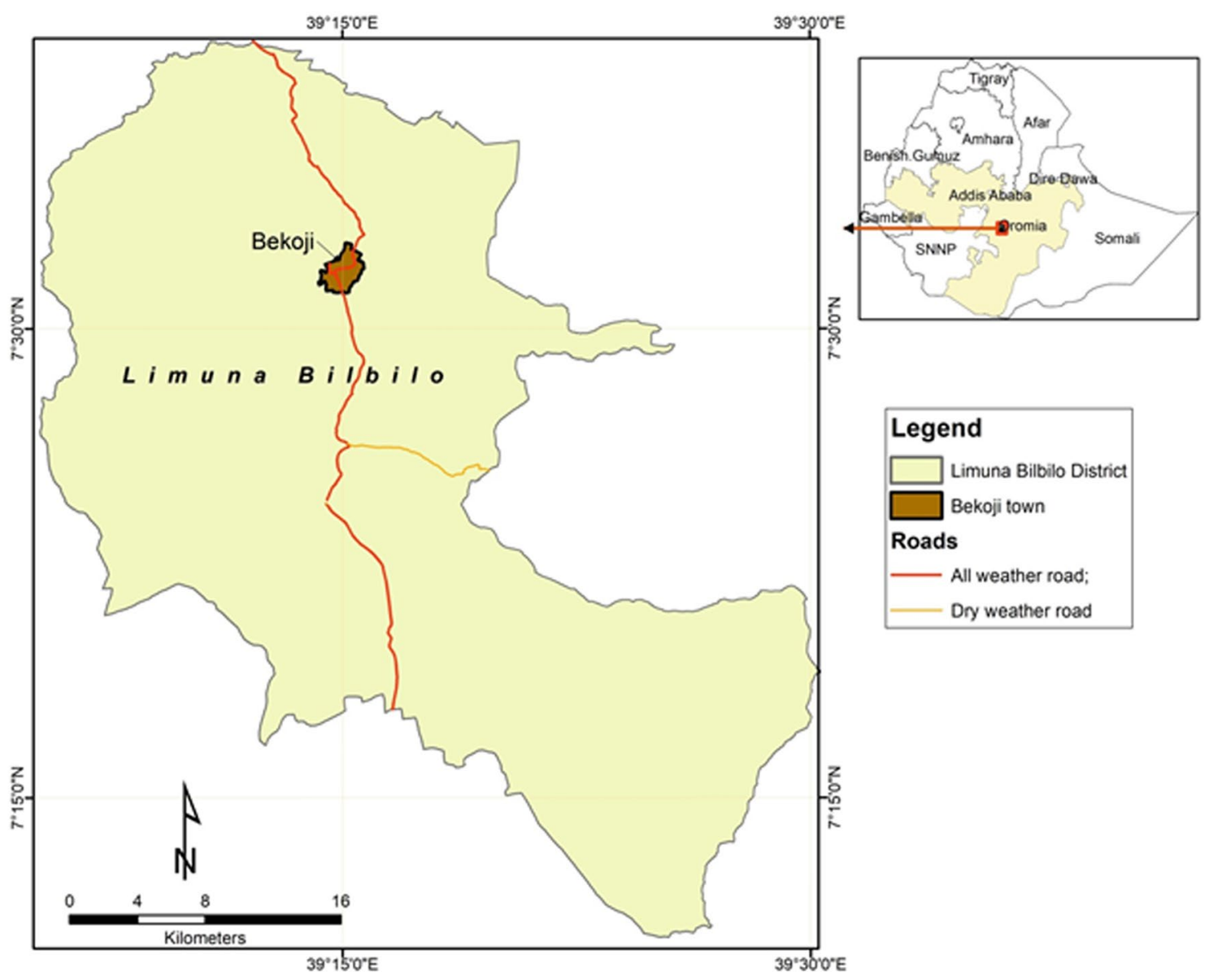

Fig. 1 Map of the experimental sites at Lemu-Bilbilo district in southeastern Ethiopian highlands

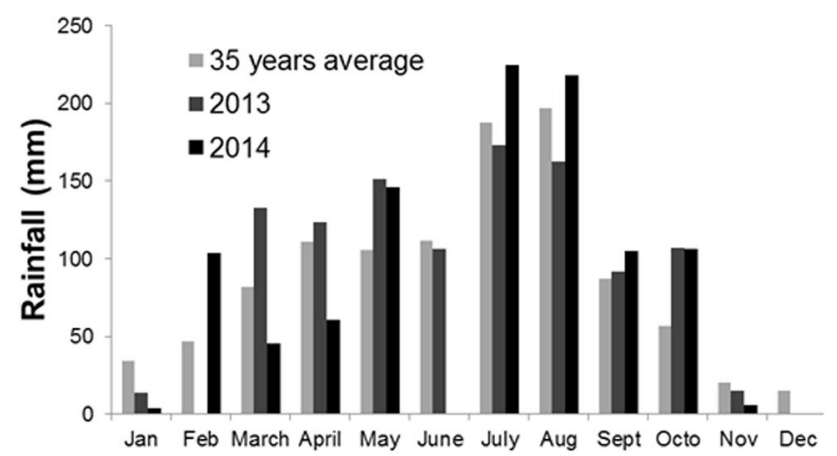

Fig. 2 Monthly total for 2013 and 2014 cropping seasons, and 35 years average rainfall at Lemu-Bilbilo district in southeastern Ethiopian highlands cows, and dried for 1 month in the shade. The $\mathrm{N}$ and moisture contents of the organic amendments were determined just before application. The amounts of compost and FYM used for this experiment were adjusted to the same rate of $36 \mathrm{~kg} \mathrm{ha}^{-1} \mathrm{~N}$ (N equivalence). Accordingly, the amounts of compost used in 2013 and 2014 were 5.9 and $5.37 \mathrm{t} \mathrm{ha}^{-1}$, respectively, on dry weight basis. The corresponding amounts for FYM were 2.05 and $2.2 \mathrm{t} \mathrm{ha}^{-1}$, respectively (Table 1).

\section{Experimental set-up and procedure}

The experiment had eight treatments, which consisted of sole and various combinations of mineral fertilizers (DAP
Table 1 Properties and amounts of compost and farmyard manure used in the field experiments

\begin{tabular}{|c|c|c|c|c|c|c|c|c|}
\hline \multirow[t]{2}{*}{ Sample type } & \multicolumn{2}{|c|}{ Total nitrogen $(\%)$} & \multicolumn{2}{|c|}{ Moisture (\%) } & \multicolumn{2}{|c|}{ Fresh matter $\left(\mathrm{t} \mathrm{ha}^{-1}\right)$} & \multicolumn{2}{|c|}{$\begin{array}{l}\text { Dry matter } \\
\left(\mathrm{t} \mathrm{ha}^{-1}\right)\end{array}$} \\
\hline & 2013 & 2014 & 2013 & 2014 & 2013 & 2014 & 2013 & 2014 \\
\hline Compost & 0.61 & 0.67 & 28.2 & 32.6 & 8.22 & 7.97 & 5.90 & 5.37 \\
\hline FYM & 1.76 & 1.64 & 82.7 & 63.1 & 11.82 & 5.95 & 2.05 & 2.20 \\
\hline
\end{tabular}


and urea) and organic amendments (compost and FYM). Details of the treatments are shown in Table 2. The treatments were arranged in randomized complete block design with three replications.

The seedbed was tilled by traditional ox plough. Compost and FYM were applied as dry matter, uniformly spread and incorporated in the top $15 \mathrm{~cm}$ soil layer by hand hoe 2 weeks prior to planting. All $\mathrm{P}$ and half of $\mathrm{N}$ were uniformly applied to all plots, except for the control treatment, as DAP and Urea, respectively; while the remaining half of $\mathrm{N}$ was top-dressed at tillering stage. All experimental plots at each site were seeded with two-row malting barley (cv. Holker) at the recommended seeding rate of $125 \mathrm{~kg} \mathrm{ha}^{-1}$. Sowing was conducted in the 3 rd to 4 th weeks of June. Seeds were drilled by hand at $0.20 \mathrm{~m}$ spacing between rows for all sites in the plot size of $2.6 \mathrm{~m} \times 4 \mathrm{~m}$. The spacing between plots and replications was 0.5 and $1 \mathrm{~m}$, respectively. Broad-leaved weeds were controlled using a herbicide, known as 2,4-D while grass weeds were manually removed. Insecticides, "Fenitrothion" and "tilt" were applied to control shoot fly and scald, respectively.

\section{Data collection}

Grain yield and above-ground biomass were harvested from the $6 \mathrm{~m}^{2}(2 \mathrm{~m} \times 3 \mathrm{~m})$ net plot areas. Above-ground biomass weight was determined after air-drying. The dried biomass was threshed manually; the grains were cleaned from straws and weighed. The moisture contents of the weighed grain samples were determined using a moisture tester device, and adjusted to the standard moisture content of $12.5 \%$ for conversion to hectare basis.

Grain protein concentrations were determined using near infrared reflectance spectroscopy. The number of tillers per plant was counted from samples of ten plants per plot. Number of spikes per plant was counted from ten sample points of $0.5 \mathrm{~m}$ length each.

\section{Economic analysis}

The procedure of partial budget analysis as recommended by CIMMYT (1988) was followed to estimate the economic benefits of integrated use of organic and mineral fertilizers. The values of total variable costs (TVC) were calculated based on farm gate prices of inputs. The variable costs estimated were the prices of fertilizers and labor for application of organic amendments before planting. Hence, TVC was calculated as the sum of the costs of compost, FYM, DAP, urea and labor. Grain and straw yields of malting barley were adjusted downwards by $10 \%$ prior to calculation. All variable costs and gross field benefits were estimated based on the average values over locations and seasons. All treatments were listed based on increasing sequence of TVC. One dominated treatment with higher variable cost, but lower net benefit was discarded from further consideration through dominance analysis. For the remaining treatments, marginal rate of return (MRR) was calculated. The minimum acceptable rate of return considered to declare economical profitability in this study was greater than or equal to $100 \%$. Based on this criterion, one treatment was eliminated from further analysis. Farmers in the study area used 65 and $75 \mathrm{~kg} \mathrm{ha}^{-1}$ DAP in 2013 and 2014, respectively. $70 \mathrm{~kg} \mathrm{ha}^{-1}$ DAP, mean value, was used to estimate the variable cost for the farmers' practice. Though the mean yield of malting barley in 2013 and 2014 in the study area was $2.71 \mathrm{t} \mathrm{ha}^{-1}$, the yield from the control treatment of this study, $3.2 \mathrm{t} \mathrm{ha}^{-1}$, was used as the farmers' practice due to the difficulty to get estimate of the straw yield from their fields. Sensitivity analysis was conducted employing the same data used for the calculation of MRR with values greater than the minimum rate of return, i.e., $100 \%$. Hence, four treatments were considered for this study (Table 7). Sensitivity analysis was made based on the assumption that all variable costs increase by $10 \%$ annually with in the coming 3 years, which make $30 \%$, while keeping the costs of produce constant.

Table 2 Treatment setup for 2013 and 2014 cropping seasons

\begin{tabular}{|c|c|}
\hline Treatment no. & Description of treatments \\
\hline 1 & Control (no input) \\
\hline 2 & Recommended nitrogen and phosphorous (RNP) from mineral fertilizers (36-20 $\mathrm{kg} \mathrm{ha}^{-1} \mathrm{~N}-\mathrm{P}$ ) \\
\hline 3 & $\begin{array}{l}\text { Recommended farmyard manure (RFYM) based on nitrogen (N) equivalence ( } 2.05 \text { and } 2.2 \mathrm{t} \mathrm{ha}^{-1} \text { in } 2013 \\
\text { and 2014, respectively) }\end{array}$ \\
\hline 4 & Recommended compost (RC) based on $\mathrm{N}$ equivalence (5.9 and $5.37 \mathrm{t} \mathrm{ha}^{-1}$ in 2013 and 2014 , respectively) \\
\hline 5 & $50 \%$ RFYM + 50\% RNP from mineral fertilizer \\
\hline 6 & $50 \% \mathrm{RC}+50 \% \mathrm{RNP}$ from mineral fertilizer \\
\hline 7 & $50 \% \mathrm{RFYM}+50 \% \mathrm{RC}$ \\
\hline 8 & $33 \%$ RFYM + 33\% RC + 33\% RNP from mineral fertilizer \\
\hline
\end{tabular}




\section{Statistical analysis}

All yield, yield components, grain quality and soil chemical properties data were subjected to analysis of variance using the general linear model procedure (Proc GLM) of SAS statistical package version 9.0 (SAS institute 2002). Mean separation was done using least significant difference test at the $5 \%$ level of probability.

\section{Results}

\section{Soil chemical properties}

Soil analysis results for the samples collected prior to planting showed that the $\mathrm{pH}$, available $\mathrm{P}$ and total $\mathrm{N}$ contents of the study sites ranged between $4.5-5.6,11-34 \mathrm{mg} \mathrm{kg}^{-1}$ and $0.22-0.32 \%$, respectively. Mean values for $\mathrm{pH}$, available $\mathrm{P}$ and total $\mathrm{N}$ of the study sites were $5.02,20.71 \mathrm{mg} \mathrm{kg}^{-1}$ and $0.28 \%$, respectively (Table 3 ).

Analysis of the soil samples collected after harvesting malting barley showed that application of either organic amendments or mineral fertilizers or their combinations significantly $(p<0.001)$ increased the available $\mathrm{P}$ and total $\mathrm{N}$ contents in the soil (Table 4). Spatial variabilities also significantly affected the soil chemical properties.

\section{Yield and yield components of malting barley}

Grain yield, total above-ground biomass, number of tillers per plant, plant population and grain protein content of malting barley were significantly $(p<0.001)$ increased by combined application of organic and mineral nutrients. The result further indicated that season and sites significantly affected most of the measured variables (Table 5).

Yields, yield-related components and grain protein concentration of malting barley were greater with all combined organic and mineral amendments than sole applications of either compost or FYM or integration of both (Table 6). The highest grain $\left(4527 \mathrm{~kg} \mathrm{ha}^{-1}\right)$ and biomass $\left(11,514 \mathrm{~kg} \mathrm{ha}^{-1}\right)$ yields of malting barley were obtained from the application of recommended rate of $\mathrm{N}$ and $\mathrm{P}$ (RNP) (36-20 kg ha ${ }^{-1}$

Table 3 Soil chemical analysis results for the experimental sites prior to application of organic and mineral amendments

\begin{tabular}{llc}
\hline Chemical properties & Values & \\
\cline { 2 - 3 } & Ranges & Mean \\
\hline $\mathrm{pH}$ & $4.5-5.6$ & 5.02 \\
Available phosphorous & $11.0-34.0 \mathrm{mg} \mathrm{kg}^{-1}$ soil & $\begin{array}{c}20.71 \mathrm{mg} \mathrm{kg}^{-1} \\
\text { soil }\end{array}$ \\
Total nitrogen & $0.22-0.32 \%$ & $0.28 \%$ \\
\hline
\end{tabular}

Table 4 Mean soil chemical properties as influenced by combined application of organic and mineral amendments after harvesting of malting barley at Lemu-Bilbilo district in southeastern Ethiopian highlands

\begin{tabular}{lll}
\hline Factor & \multicolumn{2}{l}{ Soil quality parameters } \\
\cline { 2 - 3 } & $\begin{array}{l}\text { Available P } \\
\left(\mathrm{mg} \mathrm{kg}^{-1}\right)\end{array}$ & Total N (\%) \\
\hline Control (no input) & $22^{\mathrm{c}}$ & $0.28^{\mathrm{d}}$ \\
RNP & $25^{\mathrm{a}}$ & $0.29^{\mathrm{abc}}$ \\
RFYM & $25^{\mathrm{ab}}$ & $0.29^{\mathrm{ab}}$ \\
RC & $25^{\mathrm{ab}}$ & $0.28^{\mathrm{bcd}}$ \\
$50 \%$ RFYM + 50\% RNP & $25^{\mathrm{ab}}$ & $0.29^{\mathrm{a}}$ \\
$50 \%$ RC $+50 \%$ RNP & $24^{\mathrm{ab}}$ & $0.29^{\mathrm{abc}}$ \\
$50 \%$ RFYM + 50\% RC & $23^{\mathrm{bc}}$ & $0.28^{\mathrm{cd}}$ \\
$33 \%$ RFYM + 33\% RC + 33\% RNP & $25^{\mathrm{ab}}$ & $0.29^{\mathrm{abc}}$ \\
Mean & 24.13 & 0.29 \\
CV & 9.5 & 3.35 \\
LSD & 2.18 & 0.001 \\
\hline
\end{tabular}

N-P) from mineral sources (DAP and Urea). Compared to application of full dose of $\mathrm{N}$ and $\mathrm{P}$ from mineral sources, statistically similar grain $\left(4443 \mathrm{~kg} \mathrm{ha}^{-1}\right)$ and biomass $\left(11,241 \mathrm{~kg} \mathrm{ha}^{-1}\right)$ yields were obtained from the application of $50 \%$ RNP $\left(18-10 \mathrm{~kg} \mathrm{ha}^{-1} \mathrm{~N}-\mathrm{P}\right)$ from mineral sources $+50 \%$ from compost $\left(2.95\right.$ and $2.69 \mathrm{t} \mathrm{ha}^{-1}$ in 2013 and 2014, respectively). Similarly, statistically equivalent grain $\left(4234 \mathrm{~kg} \mathrm{ha}^{-1}\right)$ and biomass $\left(10,960 \mathrm{~kg} \mathrm{ha}^{-1}\right)$ yields were obtained from the application of 50\% RNP from mineral sources + 50\% from FYM (1.03 and $1.1 \mathrm{t} \mathrm{ha}^{-1}$ in 2013 and 2014, respectively). Statistically equivalent grain yield (4037 $\mathrm{kg} \mathrm{ha}^{-1}$ ) was also obtained from the application of

Table 5 Analysis of variance of treatment effects on yield, yield components and grain quality of malting barley at Lemu-Bilbilo district in southeastern Ethiopian highlands

\begin{tabular}{llllll}
\hline Effect & \multicolumn{4}{l}{ Yield, yield components and quality parameters } \\
\cline { 2 - 6 } & $\begin{array}{l}\text { No. of } \\
\text { tillers/ } \\
\text { plant }\end{array}$ & $\begin{array}{l}\text { Spike } \mathrm{m}^{-2} \\
(\mathrm{no})\end{array}$ & $\begin{array}{l}\text { Grain } \\
\text { yield } \\
\left(\mathrm{kg} \mathrm{ha}^{-1}\right)\end{array}$ & $\begin{array}{l}\text { Biomass } \\
\text { yield } \\
\left(\mathrm{kg} \mathrm{ha}^{-1}\right)\end{array}$ & $\begin{array}{l}\text { Grain } \\
\text { protein } \\
(\%)\end{array}$ \\
\hline Rep & $\mathrm{ns}$ & $*$ & $\mathrm{~ns}$ & $\mathrm{~ns}$ & $\mathrm{~ns}$ \\
Treatment & $* * *$ & $* * *$ & $* * *$ & $* * *$ & $* * *$ \\
Year & $* * *$ & $* * *$ & $*$ & $* * *$ & $\mathrm{~ns}$ \\
Location & $* * *$ & $* * *$ & $* * *$ & $* * *$ & $\mathrm{~ns}$ \\
Mean & 3.98 & 497.52 & 3959.09 & 9866.39 & 9.89 \\
CV & 13.93 & 8.15 & 18.27 & 18.55 & 5.27 \\
LSD & 0.45 & 28.42 & 525.95 & 1330.7 & 0.62 \\
\hline
\end{tabular}

$n s$ not significant at $0.05, *$ significant at 0.05 and $* * *$ highly significant at 0.001 probability levels

Means within each column having no common superscripts are significantly different $(p<0.05)$ 
Table 6 Table of means for the effect of treatments on yield, yield components and grain quality of malting barley at Lemu-Bilbilo district in southeastern Ethiopian highlands

\begin{tabular}{|c|c|c|c|c|c|}
\hline \multirow[t]{2}{*}{ Factors } & \multicolumn{5}{|c|}{ Yield, yield components and quality parameters } \\
\hline & $\begin{array}{l}\text { No. of tillers } \\
\text { plant }^{-1}\end{array}$ & Spike $\mathrm{m}^{-2}$ (no) & Grain yield $\left(\mathrm{kg} \mathrm{ha}^{-1}\right)$ & $\begin{array}{l}\text { Biomass yield } \\
\left(\mathrm{kg} \mathrm{ha}^{-1}\right)\end{array}$ & Grain protein $(\%)$ \\
\hline \multicolumn{6}{|l|}{ Year } \\
\hline 2013 & $6.50^{\mathrm{a}}$ & $523.0^{\mathrm{a}}$ & $4034.2^{\mathrm{a}}$ & $10,182.2^{\mathrm{a}}$ & $10.02^{\mathrm{a}}$ \\
\hline 2014 & $3.14^{\mathrm{b}}$ & $305.8^{\mathrm{b}}$ & $3658.8^{\mathrm{b}}$ & $8602.9^{\mathrm{b}}$ & $9.76^{\mathrm{a}}$ \\
\hline \multicolumn{6}{|l|}{ Integrated nutrient } \\
\hline Control (no input) & $3.58^{\mathrm{c}}$ & $452.7^{\mathrm{d}}$ & $3200.2^{\mathrm{d}}$ & $7471.6^{\mathrm{e}}$ & $9.04^{\mathrm{e}}$ \\
\hline RNP & $4.17^{\mathrm{ab}}$ & $514.5^{\mathrm{a}}$ & $4527.3^{\mathrm{a}}$ & $11,514.8^{\mathrm{a}}$ & $10.65^{\mathrm{a}}$ \\
\hline RFYM & $3.58^{\mathrm{c}}$ & $483.1^{\mathrm{bc}}$ & $3668.0^{\mathrm{cd}}$ & $8578.2^{\text {de }}$ & $9.57^{\text {cde }}$ \\
\hline $\mathrm{RC}$ & $3.92^{\mathrm{bc}}$ & $475.9^{\mathrm{bcd}}$ & $3793.2^{\mathrm{bc}}$ & $9627.9^{\mathrm{cd}}$ & $9.66^{\text {cde }}$ \\
\hline $50 \%$ RFYM + 50\% RNP & $4.17^{\mathrm{ab}}$ & $489.1^{\mathrm{ab}}$ & $4234.4^{\mathrm{ab}}$ & $10,960.2^{\mathrm{ab}}$ & $10.20^{\mathrm{ab}}$ \\
\hline $50 \% \mathrm{RC}+50 \% \mathrm{RNP}$ & $4.08^{\mathrm{ab}}$ & $459.8^{\mathrm{cd}}$ & $4443.0^{\mathrm{a}}$ & $11,241.3^{\mathrm{ab}}$ & $10.37^{\mathrm{a}}$ \\
\hline $50 \%$ RFYM $+50 \%$ RC & $3.92^{\mathrm{bc}}$ & $470.6 b^{c d}$ & $3769.9^{\mathrm{bc}}$ & $9596.9^{\mathrm{cd}}$ & $9.45^{\mathrm{de}}$ \\
\hline $33 \% \mathrm{RFYM}+33 \% \mathrm{RC}+33 \% \mathrm{RNP}$ & $4.42^{\mathrm{a}}$ & $490.5^{\mathrm{ab}}$ & $4036.6^{\mathrm{abc}}$ & $9940.2^{\mathrm{bc}}$ & $10.18^{\mathrm{abc}}$ \\
\hline
\end{tabular}

RNP is recommended N and P from mineral fertilizer sources, RFYM is recommended FYM and RC is recommended compost. Results with the same letters are statistically indifferent

$33 \%$ RNP (12-7 ha $\left.{ }^{-1} \mathrm{~N}-\mathrm{P}\right)$ from mineral sources $+33 \%$ from compost (1.97 and $1.79 \mathrm{t} \mathrm{ha}^{-1}$ in 2013 and 2014 , respectively) $+33 \%$ from FYM $\left(0.68\right.$ and $0.73 \mathrm{t} \mathrm{ha}^{-1}$ in 2013 and 2014, respectively) (Table 6). The lowest yield and yield components were obtained from the control treatment.

Results depicted that large number of productive tillers per plant (4.42) was recorded from the application of $33 \%$ RNP from FYM $+33 \%$ from compost $+33 \%$ from mineral fertilizers (Table 6). However, this result was found statistically similar to the application of RNP from mineral fertilizers (4.17), 50\% RNP from mineral fertilizers $+50 \%$ from FYM (4.17), and 50\% RNP from mineral fertilizers $+50 \%$ from compost (4.08). The smallest numbers of productive tillers per plant were obtained from the control treatment, and application of RNP from either compost or FYM.

The maximum number of spikes $\mathrm{m}^{-2}$ (515 plants $\mathrm{m}^{-2}$ ) was obtained from the application of RNP from mineral sources (Table 6). However, it was found statistically similar to the application of $33 \%$ RNP from mineral fertilizers $+33 \%$ from compost $+33 \%$ from FYM (491 plants $\mathrm{m}^{-2}$ ); and the application of 50\% RNP from mineral fertilizers $+50 \%$ from FYM (489 plants $\mathrm{m}^{-2}$ ). The smallest number of spikes $\mathrm{m}^{-2}$ (453 plants $\mathrm{m}^{-2}$ ) was obtained from the application of no input (Table 6).

Yield and yield components were also significantly $(p<0.001)$ affected by seasons (Tables 6$)$ and locations (Fig. 3). Statistically, higher grain yield (4034 $\mathrm{kg} \mathrm{ha}^{-1}$ ), biomass yield (10,182 $\left.\mathrm{kg} \mathrm{ha}^{-1}\right)$, seedling density (6.5) and spikes $\mathrm{m}^{-2}$ (523 plants $\mathrm{m}^{-2}$ ) were recorded in 2013 than 2014. Due to locational differences, gain yield varied from 3352 to $4858 \mathrm{~kg} \mathrm{ha}^{-1}$ (Fig. 3).

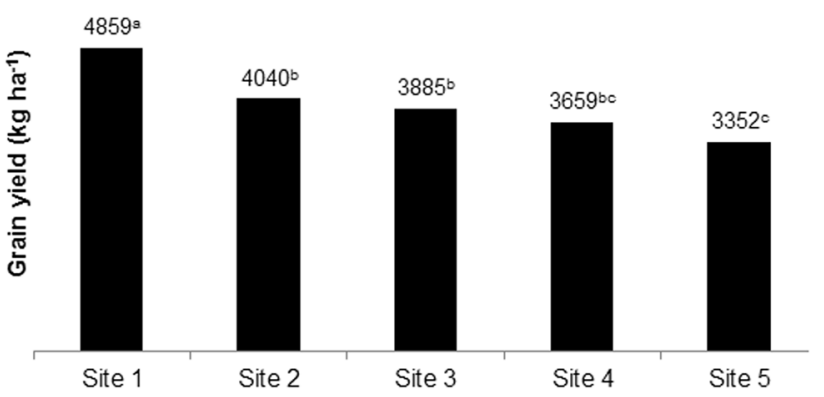

Fig. 3 Grain yield of malting barley as influenced by location at Lemu-Bilbilo in southeastern Ethiopian highlands

\section{Grain protein contents of malting barley}

Analysis of variance further revealed that the grain protein concentrations of malting barley was very significantly $(p<0.001)$ affected by the integrated use of organic and mineral fertilizers (Table 6). The highest grain protein content $(10.7 \%)$ was recorded from the application of RNP from mineral fertilizers. However, statistically similar grain protein contents were obtained from the applications of 50\% RNP from mineral fertilizers $+50 \%$ from compost $(10.4 \%) ; 50 \%$ RNP from mineral fertilizers $+50 \%$ from FYM (10.2\%); and 33\% RNP from mineral fertilizers $+33 \%$ from compost $+33 \%$ from FYM $(10.2 \%)$ (Table 6). The lowest grain protein content $(9 \%)$ was obtained from the control plot. 


\section{Economic analysis}

Combined applications of organic and mineral amendments were superior to applications of either organic amendments or mineral fertilizers and economically profitable since they gave acceptable rate of return over $100 \%$. The marginal rate of return (MRR) generally varied from 0.85 to 26.20 (Table 7). The highest MRR was obtained from the application of 50\% RNP from mineral fertilizers $+50 \%$ from FYM (26.24) followed by 33\% RNP from mineral fertilizers $+33 \%$ from FYM $+33 \%$ from compost (8.94), and full dose of RNP from compost (3.91). The net benefits improved further with combined application of 50\% RNP from mineral sources $+50 \%$ from compost (7.57). All of the four treatments used for sensitivity analysis gave MRR values in excess of $100 \%$.

\section{Discussions}

\section{Soil chemical properties}

Application of either organic amendments or mineral fertilizers or their combinations gave $7-17 \%$ (equivalent to $1.4-3.8 \mathrm{mg} \mathrm{kg}^{-1}$ ) increase in available soil $\mathrm{P}$ and $1-6 \%$ (equivalent to $0.003-0.02 \% \mathrm{~N}$ ) increase in total $\mathrm{N}$ content in the soil compared to the control treatment (Table 4). The improvements in available soil $\mathrm{P}$ and total $\mathrm{N}$ contents attributed to the additions of the aforementioned nutrients from both organic and mineral sources. Previous works also reported that integrated use of organic and mineral fertilizers resulted in the highest available soil $\mathrm{P}$ (Getachew et al. 2015) and total N contents (Getachew et al. 2014a) in the soil. The application of organic fertilizers directly influences the availability of inherent or applied P (Sharma et al. 1990). The increase in total $\mathrm{N}$ content of the soil could be attributed to the direct additions of $\mathrm{N}$ through decompositions of compost and/or FYM.
Yield and yield components of malting barley

In this study, the combined application organic and mineral fertilizers resulted in similar yields to the RNP from mineral fertilizers. The yield of malting barley and its components were substantially improved with all integrated uses of mineral and organic amendments. Combined applications of mineral and organic fertilizers from either compost or FYM at a ratio of $1: 1$ or $1: 1: 1$ gave superior grain and biomass yield advantages as compared to sole application of organic amendments, either from compost or FYM or their combinations (Tables 5 and 6). Application of 50\% RNP from mineral fertilizers $+50 \%$ from compost resulted in grain yield advantages of 17 (650), 18 (673) and 39\% (1243 $\left.\mathrm{kg} \mathrm{ha}^{-1}\right)$ as compared to RNP from compost, 1:1 ratio of compost and FYM, and the control treatment, respectively. The corresponding increments in biomass yields were 17 (1613), 17 (1645) and 51\% (3770 $\left.\mathrm{kg} \mathrm{ha}^{-1}\right)$, respectively. Similarly, application of 50\% RNP from mineral fertilizers $+50 \%$ from FYM resulted in grain yield advantages of 15 (566), 12 (465) and 32\% (1034 $\left.\mathrm{kg} \mathrm{ha}^{-1}\right)$ as compared to application of RNP from FYM, 1:1 ratio of compost and FYM, and the control treatment, respectively. The corresponding increments in biomass yields were 28 (2382), 14 (1364) and $47 \%$ (3489 $\left.\mathrm{kg} \mathrm{ha}^{-1}\right)$, respectively. This implied that the integrated use of organic and mineral fertilizers resulted in yield benefits greater than using them alone. Similar results were also reported on barley (Agegnehu et al. 2016a; Assefa 2015), wheat (Demelash et al. 2014; Getachew et al. 2014b), teff (Getachew et al. 2014b), maize (Mahmood et al. 2017; Wakene et al. 2005), Okra (Afe and Oluleye 2017) and tomato (Rajaie and Tavakoly 2016). The improved yields of malting barley due to combined application of organic and mineral amendments resulted from positive changes to the soil, including increased soil $\mathrm{pH}$, available $\mathrm{P}$ and total $\mathrm{N}$, and possibly other macro- and micronutrients.

The grain $\left(3200 \mathrm{~kg} \mathrm{ha}^{-1}\right)$ and biomass $\left(7472 \mathrm{~kg} \mathrm{ha}^{-1}\right)$ yields obtained from the control treatment were inferior.

Table 7 Economic analysis for the use of integrated organic and mineral amendments on malting barley at Lemu-Bilbilo district in southeastern Ethiopian highlands

\begin{tabular}{|c|c|c|c|c|c|c|c|}
\hline Treatments & $\begin{array}{l}\text { Adjusted grain } \\
\text { yield }\left(\mathrm{kg} \mathrm{ha}^{-1}\right)\end{array}$ & $\begin{array}{l}\text { Adjusted straw } \\
\text { yield }\left(\mathrm{kg} \mathrm{ha}^{-1}\right)\end{array}$ & $\begin{array}{l}\text { Gross field } \\
\text { benefits (US\$ } \\
\mathrm{ha}^{-1} \text { ) }\end{array}$ & $\begin{array}{l}\text { Total cost that } \\
\text { vary (US\$ } \\
\text { ha }^{-1} \text { ) }\end{array}$ & $\begin{array}{l}\text { Net benefit } \\
\left(\mathrm{US} \$ \mathrm{ha}^{-1}\right)\end{array}$ & Dominance & $\begin{array}{l}\text { Marginal } \\
\text { rate of } \\
\text { return }\end{array}$ \\
\hline RFYM & 3301.20 & 4419.18 & 1819.22 & 24.23 & 1794.99 & & \\
\hline $\mathrm{RC}$ & 3413.88 & 5251.23 & 1934.20 & 47.62 & 1886.58 & & 3.91 \\
\hline Farmers practice & 2880.18 & 3844.26 & 1586.32 & 50.43 & 1535.90 & $\mathrm{D}$ & \\
\hline $\begin{array}{l}33 \% \mathrm{RFYM}+33 \% \mathrm{RC}+33 \% \\
\text { RNP }\end{array}$ & 3632.94 & 5313.24 & 2036.96 & 57.96 & 1979.01 & & 8.94 \\
\hline $50 \%$ RFYM + 50\% RNP & 3810.96 & 6053.22 & 2174.01 & 62.99 & 2111.02 & & 26.20 \\
\hline $50 \% \mathrm{RC}+50 \% \mathrm{RNP}$ & 3998.70 & 6118.47 & 2263.03 & 73.38 & 2189.65 & & 7.57 \\
\hline RNP & 4074.57 & 6288.75 & 2310.17 & 98.87 & 2211.30 & & 0.85 \\
\hline
\end{tabular}


Applications of RNP from FYM or compost and their combinations could not also result in higher grain and biomass yields of malting barley due, possibly, to the fact that the nutrients especially $\mathrm{N}$ and $\mathrm{P}$ were not immediately available during the season to fully nourish the crop. Hence, under low soil fertility condition, integrated application of organic and mineral fertilizers is highly required because of their additive effects (Agegnehu et al. 2016a; Liu et al. 2012). Zahir and Mian (2006) reported that plots, which received $\mathrm{N}$ solely from FYM produced significantly lowest grain yield compared to other fertilizer treatments.

The number of productive tillers of barley $\mathrm{m}^{-2}$ was improved with integrated application of organic and mineral fertilizers. The current result is in agreement with Mitiku et al. (2014). The smallest numbers of tillers per plant could be attributed to the limited supply of plant nutrition from compost and/or FYM at the initial stages of growth.

Yield and yield components were also significantly affected by seasonal variations, particularly rainfall. Rainfall was very intense in 2014 cropping season, which was above the long-term average of the area for all of the months in the cropping season (June to November) (Fig. 2). The highest amount of rainfall in 2014 could have induced excess accumulation of soil moisture in the root zone, which could attribute to water logging and consequent reduction in yields compared to 2013 cropping season.

Variations in grain yields among the five studied sites were attributed to the differences in the initial nutrients contents and $\mathrm{pH}$ values of the soils. There were differences in the total $\mathrm{N}$ and available $\mathrm{P}$ contents among the soils prior to planting (Table 3 ). The site where the highest grain yield was recorded had relatively higher available $\mathrm{P}$ and total $\mathrm{N}$ contents (data not shown) compared to the other four sites. The sites with the highest $\left(4859 \mathrm{~kg} \mathrm{ha}^{-1}\right)$ and lowest (3352 $\mathrm{kg} \mathrm{ha}^{-1}$ ) grain yields (Table 4) had $\mathrm{pH}$ value of 5.6 and 4.5 , respectively. The available $P$ could have been fixed more at the low pH soils and become unavailable for malting barley.

\section{Grain protein contents of malting barley}

Similar to yield and yield components, integrated application of organic and mineral fertilizers resulted in optimum concentrations of grain protein. Agegnehu et al. (2016b), Yolcu (2015) and Miller et al. (2004) also reported significant improvements in the grain protein contents of malting barley owing to integration of mineral fertilizers with organic amendments such as biochar, cattle manure and composted manure. Applications of full dose of RNP from either compost or FYM or 1:1 compost: FYM resulted in statistically lower grain protein contents of 9.7, 9.6 and 9.5\%, respectively (Table 6). This could be attributed to the slow release of $\mathrm{N}$ from the organic amendments.
The grain protein concentrations of malting barley recorded from all treated plots were within the threshold range of grain protein content set by Assela Malt factory for malting purpose, 9.5-11\%. Despite the fact that integrated applications of organic and mineral fertilizers gave optimum values in this study, care need to be given to timing of $\mathrm{N}$ application as it significantly influences the grain protein contents of malting barley. Previous studies including Kara (2010) showed that grain protein content of malting barley increased with late-season $\mathrm{N}$ application. Therefore, it should be taken into account that $\mathrm{N}$ top-dressing of malting barley at its late stage will increase protein content in grain beyond the upper limit for malting use. The $\mathrm{N}$ requirement of the crop at its latest stage is expected to be fulfilled by the mineralization of organic amendments so that growers need to be cautious about top-dressing at booting stage. Though grain protein content of malting barley did not surpass the upper threshold limit during the 2-year study, there may be a chance of increased mineralization of $\mathrm{N}$ at the late stage of the crop development depending on environmental conditions. Therefore, seeding malting barley with low protein content, such as the variety used in this study, lowers the risk of the grain protein content exceeding beyond the threshold limit (O'Donovan et al. 2015). Besides, monitoring of grain quality on long-term application of organic amendments is required as the buildup and mineralization of $\mathrm{N}$ may increase grain protein concentrations.

\section{Economic analysis}

Combined application of 1:1 compost: mineral fertilizer could enable farmers to earn a return of US\$7.57 for every US\$1.0 investment, which implied high profitability due to integration of the locally available organic materials with mineral fertilizers. This economic benefit is on top of soil quality improvements, which we could not quantify and include their equivalent economic values in this study. Integration of FYM with mineral fertilizers also resulted in an attractive increase in farmers' income. Demelash et al. (2014) reported economical profitability with $844 \%$ MRR owing to integration of compost with mineral fertilizers in wheat production. Otinga et al. (2013) also reported an increased net benefit of over $33 \%$ in response to combined application of FYM and mineral fertilizer in maize production. Sole application of mineral fertilizers brought relatively lower revenue to farmers compared to integration with organic amendments. However, in the absence of organic amendments, investment on mineral fertilizers resulted in a very high net income to farmers with a MRR of 13.94 (Table 7) compared to the existing farmers' practice in the study area. The economic profitability agrees with the agronomic results. 
Recalculating the partial budget with the possible higher prices of total variable costs confirmed that the MRR were still above $100 \%$ minimum rate of return implying that the same recommendation could hold true. If the prices of all variable costs rise by $30 \%$ within the coming 3 years, farmers who can make the decision to apply $2.82 \mathrm{tha}^{-1}$ compost along with $18-10 \mathrm{~kg} \mathrm{ha}^{-1} \mathrm{~N}-\mathrm{P}$ will earn additional US $\$ 5.59$ for every US $\$ 1.0$ investment. The amount of compost and/ or FYM that provided optimum agronomic and economic yields could further be reduced and hence their MRR increased by vermicomposting. Shah et al. (2015) reported that farm manure inoculated with local species of earthworms produced best quality manure with enriched nutritional status including 3\% N. This result was found almost two fold of the values obtained in the current study (1.76 and $1.64 \% \mathrm{~N}$ in 2013 and 2014, respectively) implying that the amount of organic fertilizers and their associated costs could further be reduced by enhancing their quality.

\section{Conclusions and recommendation}

The present study revealed that combined application of $2.82 \mathrm{t} \mathrm{ha}^{-1}$ compost or $1.07 \mathrm{t} \mathrm{ha}^{-1}$ FYM with $18-10 \mathrm{~kg} \mathrm{ha}^{-1} \mathrm{~N}-\mathrm{P}$ or $1.88 \mathrm{t} \mathrm{ha}^{-1}$ compost $+0.71 \mathrm{t} \mathrm{ha}^{-1}$ $\mathrm{FYM}+12-7 \mathrm{~kg} \mathrm{ha}^{-1} \mathrm{~N}-\mathrm{P}$ boosted yield, grain protein concentration, soil attributes and economic benefits. Results further showed that productivity of malting barley and soil quality could be more sustainable with integration of organic amendments and mineral fertilizers than with the use of either organic amendments or mineral fertilizers alone. To counteract the decline in soil fertility on the one hand and to cope with the increasing price of the imported mineral fertilizers on the other hand, the integrated use of organic and mineral fertilizers is found to be very important. Therefore, farmers of the study area and other similar agroecologies are advised to apply 50\% recommended compost (RC) $+50 \%$ recommended NP (RNP) or $50 \%$ recommended farm yard manure (RFYM) $+50 \%$ RNP or $33 \%$ $\mathrm{RFYM}+33 \% \mathrm{RC}+33 \% \mathrm{RNP}$ for optimum ecological and economic benefits. Viable soil fertility strategies have to be implemented to make use of the available manure and crop residue resources for improving soil fertility and crop productivity by minimizing their competitive demands for fuel and feed.

\footnotetext{
Acknowledgements The authors would like to thank Ethiopian Institute of Agricultural Research for the provision of funding and logistics for the execution of this research activity. For their unreserved efforts from planting to harvesting and proper data management, all members of Land and Water Resources Research team of Kulumsa Agricultural Research Center are greatly acknowledged. The management and laboratory technician of Sinana Agricultural Research Center are also greatly acknowledged for the provision of analytical services. We
}

would also like to acknowledge the anonymous reviewers, whose comments and suggestions significantly improved this manuscript.

Open Access This article is distributed under the terms of the Creative Commons Attribution 4.0 International License (http://creativeco mmons.org/licenses/by/4.0/), which permits unrestricted use, distribution, and reproduction in any medium, provided you give appropriate credit to the original author(s) and the source, provide a link to the Creative Commons license, and indicate if changes were made.

\section{References}

Afe AI, Oluleye F (2017) Responses of Okra (Abelmuschus esculenthus L. Moench) to combined organic and inorganic foliar fertilizers. Int J Recycl Org Waste Agric 6(3):189-193. https://doi. org/10.1007/s40093-017-0166-6

Agegnehu G, Amede T (2017) Integrated soil fertility and plant nutrient management in tropical agro-ecosystems: a review. Pedosphere 27(4):662-680. https://doi.org/10.1016/S1002-0160(17)60382-5

Agegnehu G, Nelson PN, Bird MI (2016a) Crop yield, plant nutrient uptake and soil physicochemical properties under organic soil amendments and nitrogen fertilization on Nitisols. Soil Tillage Res 160:1-13. https://doi.org/10.1016/j.still.2016.02.003

Agegnehu G, Nelson PN, Bird MI (2016b) The effects of biochar, compost and their mixture and nitrogen fertilizer on yield and nitrogen use efficiency of barley grown on a Nitisol in the highlands of Ethiopia. Sci Total Environ 569-570:869-879. https:// doi.org/10.1016/j.scitotenv.2016.05.033

Assefa W (2015) Response of barley (Hordium vulgare L.) to integrated cattle manure and mineral fertilizer application in the vertisol areas of south Tigray, Ethiopia. J Plant Sci 3(2):71-76. https:// doi.org/10.11648/j.jps.20150302.15

Atlas of Arsi Zone (2002) Regional state of Oromia: Arsi zone planning and economic development office and rural development project for Arsi and Bale. Arsi, Addis Ababa

Berhane L, Chilot Y, Wondimu F (2016) Malt barley research and development in Ethiopia: opportunities and challenges. In: Dawit A, Eshetu D, Getnet A, Abebe K (eds) Proceedings of the National Conference on agricultural research for Ethiopian renaissance. Ethiopian Institute of Agricultural Research, Addis Ababa, pp $11-20$

CIMMYT (International Maize and Wheat Improvement Centre) (1988) From agronomic data to farmer recommendation: an economics training manual completely revised edition. CIMMYT, Mexico. http://repository.cimmyt.org:8080/xmlui/bitstream/handl e/10883/859/25152.pdf

CSA (Central Statistical Agency of Ethiopia) (2014) Report on area and production of major crops for 2013/2014 (private peasant holdings, Meher Season). Statistical Bulletin No. 532. Addis Ababa, Ethiopia

Demelash N, Bayu W, Tesfaye S, Zidat F, Sommer R (2014) Current and residual effects of compost and inorganic fertilizer on wheat and soil chemical properties. Nutr Cycling Agroecosyst 100(3):357-367. https://doi.org/10.1007/s10705-014-9654-5

FAO (2013) FAOSTAT 2013: Food and Agriculture Organization (FAO), Rome, Italy. http://faostat.fao.org

Getachew A, Berhane L, Paul NN (2014a) Cropping sequence and nitrogen fertilizer effects on the productivity and quality of malting barley and soil fertility in the Ethiopian highlands. Arch Agron Soil Sci 60(9):1261-1275. https://doi.org/10.1080/03650 340.2014 .881474 
Getachew A, vanBeek C, Michael IB (2014b) Influence of integrated soil fertility management in wheat and tef productivity and soil chemical properties in the highland tropical environment. J Soil Sci Plant Nutr 14:532-545. https://doi.org/10.4067/S0718-95162 014005000042

Getachew A, Michael IB, Paul NN, Adrian MB (2015) The ameliorating effects of biochar and compost on soil quality and plant growth on a Ferralsol. Soil Res 53(1):1-12. https://doi.org/10.1071/ SR14118

Gete Z, Getachew A, Dejene A, Shahidur R (2010) Fertilizer and soil fertility potential in Ethiopia: Constraints and opportunities for enhancing the system. IFPRI, Addis Ababa, Ethiopia. http://www. ifpri.org/publication/fertilizer-and-soil-fertility-potential-ethiopia

He XT, Mulvaney RL, Banwart WL (1990) A rapid method for total nitrogen analysis using microwave digestion. Soil Sci Soc Am J 54(6):1625-1629. https://doi.org/10.2136/sssaj1990.0361599500 $5400060019 \mathrm{x}$

IUSS Working Group WRB (2014) World reference base for soil resources 2014. International soil classification system for naming soils and creating legends for soil maps. World Soil Resources Reports No. 106, FAO, Rome. http://www.fao.org/3/a-i3794e.pdf

Kara B (2010) Influence of late-season nitrogen application on grain yield, nitrogen use efficiency and protein content of wheat under Isparta ecological conditions. Turk J Field Crop 15:1-6. http:// www.field-crops.org/assets/pdf/product5132156434e57.pdf

Liu J, Schulz H, Brandl S, Miehtke H, HuweB Glaser B (2012) Shortterm effect of biochar and compost on soil fertility and water status of a Dystric Cambisol in NE Germany under field conditions. J Plant Nutr Soil Sci 175:698-707. https://doi.org/10.1002/ jpln.201100172

Mahmood F, Khan I, Ashraf U, Shahzad T, Hussain S, Shahid M, Abid M, Ullah S (2017) Effects of organic and inorganic manures on maize and their residual impact on soil physico-chemical properties. J Soil Sci Plant Nutr 17(1):22-32. https://doi.org/10.4067/ S0718-95162017005000002

Mclean EO (1982) Soil PH and lime requirement. In: Page AL (ed) Methods of soil analysis. Part 2. Chemical and microbiological properties. American Society of Agronomy, Madison, pp 199224. https://doi.org/10.2134/agronmonogr9.2.2ed.c12

Mehlich A (2008) Mehlich 3 soil test extractant: a modification of Mehlich 2 extractant. Commun Soil Sci Plant Anal 15:1409-1416. https://doi.org/10.1080/00103628409367568

Miller JJ, Beasley BW, Larney FJ, Olson BM (2004) Barley dry matter yield, crop uptake, and soil nutrients under fresh and composted manure containing straw or wood-chip bedding. Can J Plant Sci 84:987-999. https://doi.org/10.4141/P03-208

Mitiku W, Tamado T, Singh TN, Teferi M (2014) Effect of integrated nutrient management on yield and yield components of food barley (Hordeum vulgare L.) in Kaffa Zone, Southwestern Ethiopia. Sci Technol Arts Res J 3(2):34-42. https://doi.org/10.4314/star. v3i2.5
Mulatu B, Lakew B (2011) Barley research and development in Ethiopia-an overview. In: Mulatu B, Grando S (eds) Barley research and development in Ethiopia. Holeta, Ethiopia, pp 1-16

O'Donovan JT, Anbessa Y, Grant CA, Macleod AL, Edney MJ, Izydorczyk MS, Turkington TK, Juskiw PE, Lafond GP, May WE, Harker KN, Johnson EN, Beres BL, McAllister TA, Smith EG, Chapman W (2015) Relative responses of new malting barley cultivars to increasing nitrogen rates in western Canada. Can J Plant Sci 95:831839. https://doi.org/10.4141/cjps-2014-415

Otinga AN, Okalebo JR, Njoroge R, Emong'ole M, Six L, Vanlauwe B, Merckx R (2013) Partial substitution of phosphorus fertilizer by farmyard manure and its localized application increases agronomic efficiency and profitability of maize production. Field Crop Res 140:32-43. https://doi.org/10.1016/j.fcr.2012.10.003

Rajaie M, Tavakoly AR (2016) Effects of municipal waste compost and nitrogen fertilizer on growth and mineral composition of tomato. Int J Recycl Org Waste Agric 5(4):339-347. https://doi. org/10.1007/s40093-016-0144-4

SAS Institute (2002) SAS Institute Inc. Cary

Shah RU, Abid M, Qayyum MF, Ullan R (2015) Dynamics of chemical changes through production of various composts/vermicompost such as farm manure and sugar industry wastes. Recycl Org Waste Agric 4(1):39-51. https://doi.org/10.1007/s40093-015-0083-5

Sharma PK, Verma TS, Gupta JP (1990) Ameliorating effects of phosphorus, lime and animal manure on wheat yield and root cation exchange capacity in degraded Alfisols of North-West Himalayas. Fert Res 23:7-13. https://doi.org/10.1007/BF02656127.pdf

USDA GAIN (USDA'S Global Agriculture Information Network) (2014) USDA GAIN: Ethiopia Grain and Feed Annual Report. GAIN Report Number: ET1401. Available at http://www.thefa rmsite.com/reports/contents/EthiopiaGrains9April2014.pdf

Wakene N, Heluf G, Friesen DK (2005) Integrated use of farmyard manure and NP fertilizers for maize on farmers' fields. J Agr Rural Dev Tropic 106(2):131-141. https://www.jarts.info/index .php/jarts/article/view/89

Yolcu H (2015) Effect of applications of organic solid cattle manure on Hungarian vetch and barley intercropping mixtures grown on soils of different depths. Grass Forage Sci 70:428-438. https:// doi.org/10.1111/gfs. 12120

Zahir S, Mian IA (2006) Effect of integrated use of farmyards manure and urea on yield and nitrogen uptake of wheat. J Agric Biol Sci 1(1):60-65. https://www.arpnjournals.com/jabs/research_paper s/jabs_0706_10.pdf

Publisher's Note Springer Nature remains neutral with regard to urisdictional claims in published maps and institutional affiliations. 